\title{
Economic Development, Foreign Aid and Poverty Reduction: Paradigm in Nigeria
}

\author{
https://doi.org/10.21272/sec.3(4).5-12.2019
}

Malachy AUgbaka, ORCID: https://orcid.org/0000-0002-2236-6420

$\mathrm{PhD}$, Assistant Lecturer, Department of Economics, University of Calabar, Nigeria

Abayomi Awujola, ORCID: https://orcid.org/0000-0002-4454-1576

$\mathrm{PhD}$, Associate Professor, PhD, Associate Professor, Department of Economics, Bingham University, Nigeria; Department of International Economic Relations, Sumy State University, Ukraine

Tatiana Shcherbyna, ORCID: https://orcid.org/0000-0001-5978-3255

$\mathrm{PhD}$, Associate Professor, Department of International Economic Relations, Sumy State University, Ukraine

\begin{abstract}
Foreign aid supplements internal resources required for economic development and growth in less developed countries (LDCs). Foreign inflows have bolstered a number of economic recuperation, reconstruction efforts and structural adjustment programs organized to haul the Africa economy out of a precarious decay. Discussions of foreign aid have concentrated on Africa since it has gotten the best measure of help on per capita premise than some other area; yet economic performance has been the weakest. In any case, economic development, foreign aid and poverty reduction has not enjoyed such interest in literature as it is ordinarily subsumed. This paper tries to build up a model between economic development, foreign aid and poverty reduction and decide if there is even a nexus between these three ideas by analyzing data from Nigeria. Utilized time series secondary data from World Development Indicators (WDI) mulling over Nigeria for the period which data were accessible. The study went on to perform correlation and regression analysis using GNP per capita as proxy for economic development as the dependent variable and poverty headcount(proxy for poverty reduction), gross capital formation, foreign aid, GDP per capita growth, inflation rate and growth of government expenditure as independent variables. It was observed that only gross capital formation have statistically significant relationship with GNP per capita while growth of government expenditure has the effect on GNP per capita. The results reveal that there is a positive relationship between economic development, foreign aid and poverty reduction. This implies foreign aid promotes economic development and poverty elimination. The government has a responsibility to battle against poverty and its efforts at predictable strategic economic development are significant in poverty reduction by spending the aid money for direct production programs.
\end{abstract}

Keywords: foreign aid, economic development, poverty reduction.

JEL Classification: O11, O15, I31, F35.

Cite as: AUgbaka, M., Awujola, A., Shcherbyna, T. (2019). Economic Development, Foreign Aid and Poverty Reduction: Paradigm in Nigeria. SocioEconomic Challenges, 3(4), 5-12. https://doi.org/10.21272/sec.3(4).5-12.2019.

(C) The Authors, 2019. This article is published with open access at Sumy State University.

\section{Introduction}

A definitive point of economic development is to wipe out poverty and raise the equilibrium position in the stationary states (LDCs) by addressing the other problems relating to human development such as education, per capita income, life expectancy, income inequality and underdevelopment. Notwithstanding the fact that severable hypotheses of economic growth for example, the Solow Growth model and the Harro-Dormar development model have been propounded in the literature, these models as enlightening as they are neglected to convert into progress in the standard of life of the general population. Poverty still remains the most basic issue defying the present reality on account of its prevalence in both developed and developing nations. 
Figures on poverty from the World development indicators report 2015 reveal that more than 1 billion individuals live on under US\$1 every day at purchasing power parity (PPP) while over 2.6 billion individuals live on under US $\$ 2$ every day at PPP. One motivation why poverty remains a pervasiveness issue is a result of its self-supporting nature as prove by the endless loop of poverty in which low income means low saving, low investment, low capital accumulation, low productivity and back to low income. With the goal for nations to develop, they should break free from this endless loop. Another test with poverty is that it is showed in a few socio-economic issues, for example, poor education, scoundrel hope, low per capita income, high income imbalance and high joblessness.

Foreign aid supplement internal assets required for investment, economic growth and development and advancement in less developed nations (LDCs). Since the most recent two decades, of the 21 st century foreign aid inflows have upheld a number of economic recuperation, reproduction endeavors and basic structural adjustment programs organized to haul the African economy out of a lofty decrease (Adam, 2008). The aid syndrome introduces a significant test to policy makers in light of the fact that foreign aid may likewise present or create unfortunate impacts which are usually known as Dutch ailment (a term which comprehensively alludes to the destructive results of huge inflows of foreign currency into a nation) in macroeconomics writing.

Dialogs of foreign aid have concentrated on Africa since it has gotten the best measure of help on per capita premise than some other regions; yet economic progress has been the weakest (Iyoha, 2004). The poor progress in economic performance has been related with terrible administration, official corruption/defilement and macroeconomic instability in the region. In spite of its abundant oil assets Nigeria's economic performance has been startlingly poor. Per capita income has endured noteworthy disintegration since the crest in the mid1980s that happened when oil prices were at chronicled abnormal rates (Adam and Obansa, 2010).

Basically, development implies improvement or to turn out to be further developed, increasingly develop, progressively complete, increasingly sorted out, progressively changed. Todaro and Smith (2009) consider improvement to be a 'multi-dimensional procedure including the redesign and reorientation of the whole economic and social framework. Notwithstanding development of income and output, this includes radical changes in institutional, social and regulatory structures just as in well-known frames of mind, traditions and conviction. This definition gives the implying that development accepts at whatever point it is examined in connection to nations. Ibezim (1999) presents that economic development does include physical and financial related improvements as well as upgrades in the political and social parts of the general public.Dada (2008) sees economic development as the capacity of government to raise the standard of living of the populace by moving them from a condition of less attractive quality to a condition of higher allure through purposeful, cognizant and deliberately centered structured and implementable projects and tasks.

The objective of this paper is to analyze the presence of direct empirical connection between economic development, foreign aid and poverty reduction in Nigeria. It further tries to decide the most significant variable influencing poverty and the impact of this variable in Nigeria. This examination is significant in light of the fact that literature on this subject is sparse as the relationship between economic development, foreign aid, and poverty reduction has not been completely examined. The issue of economic development, foreign aid and poverty reduction still remains a noteworthy issue in research area. However economic development, foreign aid, and poverty reduction paradigm has not enjoyed such luck as it is conventionally assumed. The paper hence looks to set up a direct link between economic development, foreign aid and poverty reduction in Nigeria. The paper utilizes time series secondary data from the world development indicators of the World Bank and the National Bureau of Statistics.

The paper is structured into five segments. The first segment is the introduction to the study, which introduces a general review of the paper. The second segment is the theoretical framework and literature review; the third segment is the methodology and model specification. The fourth segment is the data and interpretation of results and last segment concludes the paper, presents recommendations for further research.

\section{Theoretical Framework}

\subsection{The Two Gap Model}

Most literature consulted for this study recognizes the fact that foreign aid inflow influence development through their effect on investment (Gomanee et al., 2002). As indicated by Bulio and Lane (2002), poor 
nations need adequate assets to fund development and imports capital products just as innovation. The Gap Model advanced by Chenery and Strout (1966) a very long time back is still being used in anticipating the macroeconomic effect of foreign aid.This model has two parts consequently it is likewise regularly alluded to as the Two-Gap Model. The principal segment is the relationship between investment and development, wherein the dimension of development is thought to be subject to the level of investment. The second segment is the relationship between savings, which is expected as a basic factor for investment development, and growth.

With this model, experts can decide the fundamental dimension of investment to accomplish an ideal level of economic development. Gaps occur if the investment is below the ideal dimension and these gaps can be attributed as either a saving hole or as a foreign trade (or exchange) hole.In the event that a nation is unfit to fill this gap through imports, exports or production, foreign aid inflows are required with the goal that it can develop more quickly than its domestic assets would some way or another permit. Henceforth an inflow of foreign aid should move a nation's economy upwards.

\subsection{The Poverty Trap Model}

The poverty trap model is in reality to a greater degree a hypothetical structure than an econometric one. The earliest poverty trap model was utilized by Nelson (1956).Dissimilar to the gap model which considers unfamiliar to be as an approach to raise investment and accordingly impact development, this model expect that development is hampered by poverty traps which can emerge out of different elements like low production capacity, high populace, and weak savings. Notwithstanding the causes, poverty traps are believed to compromise development. Foreign aid, which is an impermanent infusion of capital, is accepted to enable the economy to escape the poverty trap and take-off towards development.

\section{Literature Review}

Here, we review studies that focus on this subject and their potential results. Studies on this subject are relatively small as there is considerable shortage of literature on the subject. There are no proofs to support the combined empirical analysis of the relationships between economic development, foreign aid and poverty reduction. In light of this reality consequently, we utilize different investigations on foreign aid, poverty reduction and economic development autonomously and attempt to wed them together in an attempt to establish the previous studies on the subject.

According to Boye (2019) examined the impact of foreign aid on poverty reduction in Ghana economy 2008 to 2018. The findings showed that foreign aid does not have an impact on poverty reduction. A Bounds Test for cointegration was also employed and the results showed a long-run relationship among the variables.

The study of Tersoo and Abubakar (2019) re-examines the efficacy of foreign aid and grants on poverty reduction in Nigeria using time series data covering the period of 1999 to 2017 applied the Autoregressive Distributed Lag (ARDL) bounds testing approach to establish the variables relationship. The results showed that Technically Cooperation Grants and Official Development Assistance have positive but insignificant impact on national poverty incidence in the short-term horizon; however, in the long-term, then effect of TCG and ODA on poverty incidence is negative.

Roosevelt (2018) examined impact of foreign aids on extreme poverty in Liberia development complexities. This research explains the ways in which aid perpetuates poverty instead of alleviating it using interdisciplinary research approaches. The findings showed poverty persists despite billions of dollars in aid and inequalities.

Bakare (2010) investigated the determinants of the urban joblessness in Nigeria. The variables for the investigation incorporate level of joblessness and demand for labour, supply of labour, populace, inflation, capacity utilization, gross capital formation and nominal wage rate. Utilizing time series secondary data and parsimonious error correction mechanism, the examination found that the rising nominal wages and the accelerated growth of population which influenced the supply side through a high and fast increment in labor force with respect to the absorptive capacity of the economy have all the earmarks of being the principle determinant of high joblessness in Nigeria.

Bello and Abdul, (2010) analyzed poverty situation in Nigeria by utilizing the data of economic growth and millennium development goals (MDGs) expenditure. The study utilized panel data analysis consisting of pooled model, fixed-effects, random-effects and weighted least square. The outcomes uncovered that; a unit 
increment in per capita GDP prompted 0.6 percent expansion in poverty. Additionally, a unit increment in MDG use brought about 11.56 units increment in relative poverty in the pooled model. The investigation inferred that economic growth and MDG spending has not considerably diminished poverty over the example time frame.

Adam (2010) deduced that foreign aid is emphatically identified with investment, economic growth and exchange rate and adversely identified with inflation. In his study the relationship that exist between foreign aid and selected macroeconomic variables in Nigeria, the study submits that the use of foreign aid should be encouraged since it promotes investment which leads to economic growth and development and it is not inflationary. As a result, international community should set up their aid assistance to developing countries by meeting their pledges to increase aid flow.

Burnside and Dollar (2000) contended that aid can be effective when strategies are great, that is, well articulated monetary and fiscal policies. Three principle contention have been progressed to clarify the disappointment consequences of strategic reasons of most aid viability studies; aid ismisallocated (contributors give help for key motivations to the wrong beneficiary), aid is abused (beneficiary government seek after non-development plans) and GDP growth isn't the correct proportion of aid adequacy. Most literature on aid effectiveness define donor's objective as solely the promotion of economic growth and development or reduction of poverty in recipient's countries, another strand of literature contend that aid is apportioned for vital purposes, no positive effect as far as development or poverty alleviation should be expected.

Foreign capital inflows are supported in light of the fact thatthey increase real income resulting from the investment that capital is employed. An increase in employment and real wages may be another major benefit from an inflow of foreign capital (Obadan, 1999, Pallage and Robe, 2001). As per Bulio and Lane (2002), restriction is a noteworthy wellspring of foreign aid instability. This does not only apply to the conditions attached by bilateral donors; but frequently, the requirements that aid recipient have the approval of an on track IMF supported program.

In summary, previous studies have not examined the effectiveness of aid in tackling economic development and poverty reduction in Nigeria where is widely believed or accepted as poverty capital nation of the world. The paper intends to fill this gap by examining whether foreign aid affects economic development and poverty reduction in Nigeria.

\section{Methodology and Model Specification}

In this section, we present the philosophy and model detail of the paper. This study is undertaken with the main aim of examining the existence of a direct empirical relationship between economic development, foreign aid inflows and poverty reduction in Nigeria. It further seeks to determine the most significant economic development variables influencing poverty and the impacts of these variables in the economy. A few studies in examining aid-growth nexusemploy cross-country or panel-data approaches where nations are lumped together regardless of their disparities. To accomplish this objective, an econometric instrument dependent on Ordinary Least Square (OLS) is utilized to examine the exact relationship among the variables. The aim of the paper is to decide whether a relationship exists between economic development, foreign aid and poverty reduction in Nigeria. Foreign aid as indicated by Adam and Obansa (2010) underpins domestic resources needed to promote economic development and reduce incidence of poverty in underdeveloped countries. Iyoha (2004) includes that foreign aid is indispensable in quickened economic development and eliminating poverty in developing countries while Todaro and Smith (2009) prove this attestation by saying that foreign aid which is the transferring of resources from developed countries to less developed countries is aimed at development, poverty reduction and or income distribution. While the objective of economic development according to Iyoha (2004) is that it would aid in the significant improvement of the well-being of the poor, increase the welfare of all the members of the society, and a significant reduction of poverty incidence among others. These opinions clearly support the assertion that external resource inflows supplements domestic resources for investment and economic development in developing economies. In this manner, we did correlation investigation on the macroeconomic variables of the study. The correlational outcome shows a solid positive relationship between the variables. Therefore, we carried out correlation analysis on the macroeconomic variables of the study. The correlational result reveals a strong positive correlation between the variables. 
The model for the economic development, foreign aid and poverty reduction is the accompanying useful relationship:

$F O A_{t}=f\left(P H C_{t}, G N P_{t}, G D P_{t}, I N F_{t}, G C F_{t}\right)$

While the OLS estimation model is stated as:

$F O A_{t}=\beta_{0}+\beta_{1} P H C_{t}+\beta_{2} G N P_{2}+\beta_{3} G D P_{3}+\beta_{4} I N F_{4}+\beta_{5} G C F_{5}+\mu$

Where: FOA is concessional loans in the form of aid commonly referred to as official development assistance (ODA); PHC is the ratio of the percentage of the population living on the less than $\$ 1.9$ per day at PPP (purchasing Power parity);GNP is per capita which is the growth rate of the dollar value of output of goods and services which reflects the average income of the citizens from year to year; GDP is per capita growth which is measured as the percentage growth of per capita income from one year to another; INF is the rate of price change in the economy and GCE is the annual percentage growth rate of the general government final consumption expenditure; $\mu$ is the error term.

Our prior expectation is such the values of $\beta_{2}, \beta_{3}$ and $\beta_{5}$ are to be negative, while the values of $\beta_{1}$ and $\beta_{4}$ are to be positive. $\beta_{2}$ is relied upon to be negative since Nigeria is a nation related to the phenomenon of the utilization of foreign aid for investment and economic development, as more assets from developed nations are conveyed into the nation, more occupations would be made that will at last diminish the dimension of poverty. $\beta_{3}$ should be negative since it is perceived from literature that higher GDP growth is required to stream down to by far most of the populace. So also, $\beta_{5}$ is relied upon to be negative since increment in government consumption expenditure is required to achieve the majority through medicinal services and other basic social administrations which will in the long run lead to a radical decrease in poverty figures. Then again be that as it may, we expect $\beta_{1}$ to be positive on the grounds that population growth is an issue of welfare. As the population expands, it exact pressure on government resources since development entails the improvement in peoples levels of living - their incomes, health, education, and general well-being. What's more, $\beta_{4}$ is required to be positive in light of the fact that higher inflation which is a macroeconomic phenomenon affects real income of the majority prompting extreme hardships and poverty deepening.

\section{Analysis of Data and Interpretation of Results}

\subsection{Summary statistics}

The significant of summary statistics is to give a brief description of the measures of central tendency and to show whether the data set are normally distributed. The summary statistics table is given in Table 1 .

\subsection{Unit root test}

Time series data normally exhibit non-stationary behaviour in their level if not purged of their unit root propensities will generally presents a potential threat for any econometric examination consequently prompting fake results. The significance of this is drives from the fact that estimation within the presence of non-stationarity in variables normally leads to conflicting inference of the standard error of the coefficients and this could prompt deceiving deduction if proper procedure isn't used to conquer the issue. The unit root tests are carried out using the Augmented Dickey-Fuller (ADF). The results of the unitroot tests are displayed in table 1.

Table 1. Result of Unit Root Test

\begin{tabular}{|c|c|c|c|c|}
\hline Variables & Level & 1st Difference & 2nd Difference & Remark \\
\hline PHR & -2.8668 & $-3.9245^{* *}$ & & $\mathrm{I}(1)$ \\
\hline GCF & $-3.7506^{* *}$ & & $\mathrm{I}(0)$ \\
\hline FOA & -28504 & -35523 & $-5.1640^{*}$ & $\mathrm{I}(2)$ \\
\hline GDP & -2.9950 & $-6.0608^{*}$ & & $\mathrm{I}(1)$ \\
\hline INF & -3.9525 & & & $\mathrm{I}(0)$ \\
\hline GGE & -2.8688 & $-5.7256^{*}$ & $\mathrm{I}(1)$ \\
\hline
\end{tabular}

Source: Authors' computation using E-view 8.1; *,**,*** denotes 0.01, 0.05,0.10 levels of Significance.

The unit root test above reveals that gross capital formation and inflation are stationary at level, poverty headcount ratio; foreign aid, GDP per capital growth and growth of government consumption expenditure are stationary at first difference while population growth rate is stationary after second difference. Therefore, the variables would be differenced appropriately. 
Table 2. Estimates of Test Results

\begin{tabular}{|l|c|c|}
\hline \multicolumn{1}{|c|}{ Regressor } & Coefficient & t-value \\
\hline \multicolumn{1}{|c|}{ Constant } & 90.01510 & 4.978642 \\
\hline \multicolumn{1}{|c|}{ GCF } & 0.821391 & 2.884395 \\
\hline \multicolumn{1}{|c|}{ PHC } & 1.435755 & -3.118639 \\
\hline \multicolumn{1}{|c|}{ INF } & 0.267222 & 0.350392 \\
\hline $\begin{array}{l}\text { GGE } \\
\text { Summary of statistics: }\end{array}$ & 0.122929 & 0.179374 \\
\hline$R^{2}=0.570856$ & & \\
\hline Dw statistic $=0.939454$ & Adj $R^{2}=0.427808$ & \\
\hline
\end{tabular}

Source: Authors' computation from E-view 8.1.

The outcome above demonstrates a high value for the constant at 90.02 when the various variables are equivalent to zero. A 1 per cent change in gross capital formation prompts a 0.82 percent change in foreign aid in the same direction. A 1 per cent change in poverty headcount ration prompts a 1.44 per cent change in foreign aid in the opposite direction. A 1 per cent change in gross national product leads a to 3.13 per cent change in foreign aid in the same direction. A 1 per cent change in GDP per capita growth leads to a 2.19 per cent change in foreign aid in the same direction. A 1 per cent change in inflation rate leads to a 0.27 per cent change in foreign aid in the same direction while a 1 per cent change in growth in government expenditure leads to a 0.12 per cent change in foreign aid.

The R-square is 0.57 , which implies 57 per cent of the changes in foreign aid can be explained by gross capital formation, poverty headcount ration, gross national product, GDP per capita growth, inflation rate and growth of government expenditure. The Durbin Watson statistic of 0.939 shows the presence of high positive autocorrelation. This autocorrelation may be as a result of the inclusion of economic growth in the model or the omission of some variables such as unemployment rate which is a common motivational factor for foreign assistance. Among all the variables, only gross capital formation and population headcount ratio are statistically significant in determining foreign aid. In addition, population headcount ration and inflation rate are in agreement with a prior expectation while the other variables go against our expectation.

In addition to this, the correlation matrices for the variables were obtained. The matrices were taken for the times series data of the study. The result is given in Tables 3. Table 3 shows the correlation matrix for the time series data. According to the table, gross capital formation,GDP per capita growth, and growth of government expenditure all have a weak negative linear relationship with foreign aid with values of -12.89 percent, -30.73 per cent, and -24.62 per cent, respectively. On the country, poverty headcount ration have a medium positive relationship with foreign aid (42.18 per cent and 44.41 per cent respectively) while inflation rate has a weak positive linear relationship with foreign aid (32.86 per cent). This shows the huge potential for GDP per capita growth to reduce the poverty incidence if only the problem of income inequality can be solved.

Table 3. Correlation Matrix for the Time Series data

\begin{tabular}{|c|c|c|c|c|c|c|}
\hline FOA & GCF & PHC & GDP & GNP & INF & GGE \\
\hline 1.0000 & -0.1289 & 0.4218 & 0.4441 & -0.3073 & 0.3286 & -0.2462 \\
\hline & 1.0000 & 0.5264 & -0.5208 & 0.5887 & -0.3549 & 0.5167 \\
\hline & & 1.0000 & -0.9297 & 0.8721 & -0.6933 & 0.6696 \\
\hline & & & 1.0000 & -0.8704 & 0.7740 & -0.6848 \\
\hline & & & & 1.0000 & -0.6166 & 0.7494 \\
\hline & & & & & 1.0000 & -0.5263 \\
\hline & & & & & & 1.0000 \\
\hline
\end{tabular}

Source: Authors' computation from Eview 8.1.

\subsection{Policy implications}

The study has brought to the fore certain issues which are significant and require important strategy activity in the battle against poverty. To begin with, it is significant for the legislature to take part in successful steady key economic development so as to accomplish poverty reduction. This means the legislature should utilize short, medium and long run economic development strategies designs so as to battle poverty. The short and medium terms programs ought to be very much enunciated to keep them in accordance with the long run plan. 
The programs must be compelling in that they ought to be explicit, have quantifiable advancement and be opportune, all together words; it ought to have the option to meet explicit focus inside a given timeframe.

Second, gross capita formation and poverty headcount moves in a similar way and this implies an expansion in gross capital formation would prompts an expansion in poverty headcount proportion. This, however, should not demoralize the government from taking part in gross capital formation. Rather, it demonstrates that past efforts at capital formation have been misled; that is, they generally affect the rich which exacerbated the issue of income disparity and intensifies as opposed to improve the issue of poverty. Along these lines, the government needs to search for better approaches to channel its capital towards the poor by building infrastructure in rural areas to create employment and by concentrating all the more seriously on advancement of human capital through progress in education and wellbeing, particularly in rural areas.

Gross domestic product per capita growth is slanted against poverty headcount proportion and some of the time intensifies the poverty circumstance in view of income disparity. As GDP per capita is expanding, it doesn't get too the poor masses, however remains in the hands of the rich and may in the end be lost due to capital flight which is normal in the nation, yet greater part of the general population suffers from wretched poverty. The government needs to address the issue of income disparity to guarantee that GDP per capita growth streams down to the majority. It can do this by suitably changing the size and functional distributions of income.

Inflation is a noteworthy issue confronting poverty individuals who are for the most part fixed breadwinners and low salary workers as it disintegrates their purchasing power and makes them increasingly unfit to live easily. The most significant inflationary weights influencing the poverty individuals are nourishment and energy on the grounds that those are fundamental necessities of life for everyone. The government needs to control inflation in its offer to eliminate poverty.

Government expenditure additionally exacerbates the poverty circumstance. This can be ascribes to the way that government expenditure has been inadequate in tending to poverty. The government is spending more on the military and on security to the impairment of the general population. What's more, because of the issue of corruption which is widespread, reserves which have been diverted into development don't get the chance to contact the general population for which they were expected. There is a need, in this manner, for government to concentrate more on spending to improve the living states of the majority since this would go far in controlling interior emergencies. The government should likewise battle corruption and guarantee that cash spent is all around represented and that economic improvement is accomplished and poverty is diminished.

In conclusion, the government desperately needs to overhaul plans on gross capital formation, population growth, GDP per capita growth, inflation and government expenditure growth plans and correct them appropriately in order to reduce to the barest minimum the high rate of poverty in the country.

\section{Conclusion and Suggestions for Future Research}

The examination has demonstrated that foreign aid is positively related to economic development and poverty reduction. This implies foreign aid promotes economic development and poverty elimination. The government has a major task to carry out in the battle against poverty and its efforts at predictable strategic economic development are significant in poverty reduction by spending the aid money for direct production programs. The government which is main recipient of aid should also implement policies that will offset the tendency of foreign aid to generate employment opportunities.

It is profoundly significant for further research to be done on this field since literature on the empirical relationship between economic development, foreign aid and poverty reduction with unique spotlight on poverty is sparse. This investigation confronted a noteworthy test in absence of sufficient information particularly on poverty and on imbalance and joblessness. Therefore, those two factors couldn't be incorporated into the examination. Besides, the investigation would be better completed by utilizing a general harmony model which would consolidate more variables and give a progressively point by point examination with regards with the relationships of anticipating the different sectors of the economy and poverty decrease. 


\section{References}

1. Adam, A.J. (2008). International Perspectives on Aid Coordination in Developing Countries. The Ecosight Magazine, NESA Publication, $4^{\text {th }}$ Edition, University of Abuja.

2. Adam and Obansa (2010). Nigeria's Macroeconomics Development: Issues and Challenges. Richard \& Partners, First Published. Abuja, Nigeria.

3. Anyanwu, J., A. Oyefusi, H. Oaikhenana, and F.A Dimowo (1997). The Structure of the Nigerian Economy (1960 - 1997). Ibadan: Joanee Educational Publishers Limited.

4. Bakare A.S. (2010). The Determinants of Urban Unemployment Crisis in Nigeria: An Econometric Analysis. Journal of Emerging Trends in Economics and Management Sciences (JETEMS), 2(3), 184192, https://pdfs.semanticscholar.org/19ee/5a198585a0a0f3d66a23e822f2bfc8fd0419.pdf.

5. Bello, M.A. and Abdul, H.R. (2010). Has Poverty Reduced in Nigeria 20 Years After? European Journal of Social Sciences, 17-36. https://www.researchgate.net/publication/283235391_Has_poverty_reduced_in_Nigeria_20_years_after

6. Boye, R.A. (2018). Impact of Foreign Aid on Poverty Reduction in Ghana. URL: http://ugspace.ug.edu.gh/handle/123456789/32387.

7. Bulir A. and T. Lane (2002). Aid and Fiscal Management. IMF working Paper WP/02/112, Washington DC. https://www.imf.org/en/Publications/WP/Issues/2016/12/30/Aid-and-Fiscal-Management-15880

8. Business Day (2010). Aid inflow to developing countries. Business day newspaper, November 12. https://www.businesslist.com.ng/company/129685/thisday-newspaper.

9. Chenery, H.B. and A.M Strout (1966). Foreign assistance and economic development, American Economic Review, 56 ,

$232-253$ https://www.scirp.org/(S(i43dyn45teexjx455qlt3d2q))/reference/ReferencesPapers.aspx?ReferenceID=139345 $\underline{8}$.

10. Dollar, B. (1998) Aid, the incentive regime and poverty reduction. Policy Research Working Paper. Washington D.C The World Bank. http://documents.worldbank.org/curated/en/143851468764416188/Aidthe-incentive-regime-and-poverty-reduction.

11. Fosu, A.S. (2011). Growth, inequality and poverty reduction in developing countries. UNU-WIDER Working Paper No. 2011/01. https://ideas.repec.org/p/unu/wpaper/wp2011-01.html

12. Gomanee, K. S.et al. (2002). Aid and growth in Sub-Saharan Africa: Accounting for transmission mechanisms. Credit Research Paper, University of Nottingham, England.

13. Pallage, S and M. Robe (2001). Foreign aid and the business cycle, Review of International Economics, 9(4), 50-68. https://doi.org/10.1111/1467-9396.00305.

14. Roosvelt Seedee (2018). Impact of Foreign Aid on Extreme Poverty in Liberia's Development Complexities, https://dc.etsu.edu/etd.

15. The World Bank: World Development Indicators (2015). Washington, D.C: The World Bank. http://documents.worldbank.org/curated/en/795941468338533334/World-development-indicators-2015.

16. Todaro, M.P. and Smith, S.C. (2009). Economic Development (Tenth Edition). New Jersey: Pearson Education Limited. https://www.pearson.com/us/higher-education/product/Todaro-EconomicDevelopment-10th-Edition/9780321485731.html

17. Tersoo, S.S. \& Abubakar, S. (2019). Re-examined the Efficacy of Foreign Aid and Grants in Poverty Reduction in Nigeria. Asian Economic and Financial Review, 9(4), 450-460. DOI: $\underline{10.18488 \text { /journal.aefr.2019.94.450.460. }}$ 